\title{
Article
}

\section{It's All About Games: Enterprise And Entrepreneurialism In Digital Games.}

\author{
Wright, Adrian \\ Available at http://clok.uclan.ac.uk/13363/ \\ Wright, Adrian ORCID: 0000-0003-2803-212X (2015) It's All About Games: \\ Enterprise And Entrepreneurialism In Digital Games. New Technology, Work \\ And Employment, 30 (1). pp. 32-46.
}

It is advisable to refer to the publisher's version if you intend to cite from the work. http://dx.doi.org/10.1111/ntwe.12042

For more information about UCLan's research in this area go to

http://www.uclan.ac.uk/researchgroups/ and search for <name of research Group>.

For information about Research generally at UCLan please go to http://www.uclan.ac.uk/research/

All outputs in CLoK are protected by Intellectual Property Rights law, including Copyright law. Copyright, IPR and Moral Rights for the works on this site are retained by the individual authors and/or other copyright owners. Terms and conditions for use of this material are defined in the policies page.

\section{CLoK}

Central Lancashire online Knowledge www.clok.uclan.ac.uk

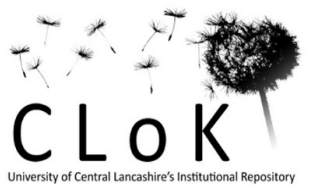


Title: It's All About Games: Enterprise And Entrepreneurialism In Digital Games.

\begin{abstract}
This article aims to contrast benign notions of 'free' and 'creative' work in the context of labour market conditions and employment relationships. Empirical research reveals the exploitative and precarious nature of work in the experiences of self-employed digital game developers and charts the responses of developers to unstable and insecure working conditions. Building on work by Pongratz and Voß (2003), Haunschild and Eikhof (2009), and Bergvall-Kåreborn and Howcroft (2013), this study finds that a typical response to increasing instability in the labour market is to adopt more enterprising and entrepreneurial behaviour in order to find work. This article illustrates the consequences for developers by highlighting examples of self-exploitation, which is fuelled by a passion for work and is where entrepreneurial practices lead to long working hours, unpaid work and a blurring of work-life boundaries.
\end{abstract}

\title{
Introduction
}

Despite considerable published research on creative industries such as music, TV and film, the digital games sector has been comparatively under-researched even given its growing symbolic and economic significance. Similar in economic size to the Hollywood film industry (Zackariasson et al, 2006) the digital games sector is worth $\$ 68.3$ billion globally and around f2.9 billion to the UK economy (Euromonitor, 2014), with the UK constituting the third largest sector in the world (Skillset, 2011). An exemplar of the symbolic significance of the industry is the console title Call of Duty: Black Ops 2, which was the UK's biggest selling entertainment release of 2012 (BBC News, 2012).

Despite the success of the digital games sector in the UK it has been regarded as a risky industry characterised by unstable macro conditions. Games firms have had to adapt to major technological change impacting on product innovations and power relations in the sector 
(Parker et al, 2014), government U-turns and European Commission investigations over tax breaks (Keynote, 2014) and, in addition, the changing demographic of users which has influenced consumption (Prato et al, 2010). Furthermore, instability exists in the labour market which is evidenced by employment statistics and the constitution and structure of firms. The number of developers working in the sector in the UK declined to 7,000 in 2009 from an industry high of 9,400 in 2004 (Skillset, 2011). An accelerating trend of vertical integration in the mid-2000's, where smaller independent companies were acquired by larger publishers (Phillips et al, 2009), can be contrasted by more recent evidence suggesting the UK sector is characterised by small development teams, with a vast majority of companies ( 80 percent) having fewer than 4 employees. Recent statistics suggest only 5 per cent of firms in the sector are comprised by those which have between 100 and 249 employees (Keynote, 2013).

An explanation for the changing constitution and structure of the sector can be found in significant innovations in business models. The distribution of smartphone handsets, the affordability of mobile data plans and the arrival of tablet computers have offered opportunities for developers to develop new types of games. Consequently, mobile has become the fastest growing gaming platform (Stewart and Misuraca, 2013) and will reach $\$ 11.4$ billion in global revenue by 2014 (Parker et al 2014).

The rapid growth of the sector, dynamic changes to digital games products and emerging technologies have lowered the barriers to entry and affected working practices. Increasing accessibility to digital platforms has encouraged the supply of online content. Apple's iPhone Software Development Kit (now iOS software development kit) and Google's open source Android platform have allowed mobile apps to be developed and sold on the App store and Google Play stores respectively (Bergvall-Kåreborn and Howcroft, 2013). This critical lowering of barriers to entry has allowed third party game developers to gain employment to the industry amid unstable labour market conditions, rather than the alternative of seeking employment outside this industry niche. Perhaps the lowering of barriers in entry provides an explanation for the changes to the constitution of firms in the sector and the trend towards smaller 
development teams. These changes give developers choices in terms of work and employment, whether to work as an employee or freelance or to work in an independent studio as a selfemployed developer.

Nascent research in the area of digital games has tended to focus on managerial tensions when reconciling creative, technical and commercial imperatives (Tschang, 2007), the quality of work life and exploitative working conditions (Robinson, 2005), employment relationships (Peuter and Dyer-Witheford,2005), managerial control (Cohendet and Simon, 2007) and evolution of skills development (Izushi and Aoyama, 2006). However, work typically has focused on the relationship between console game manufacturers and developers, not recognising new working practices in other areas of games production. Only a limited number of studies (Haunschild and Eikhof,2009; Bergvall-Kåreborn and Howcroft,2013; Coulsen,2012) discuss how unstable labour market conditions lead to entrepreneurial activity amongst workers. Faced with contrasting accounts of the impact of precarious labour market conditions on creative workers, the aim of this article is to examine the experiences of a cohort of digital games developers in a sector that is, by contemporary prescription, creatively empowered and entrepreneurial. Specifically, the article will consider the consequences for work and employment in the local sectoral labour market, which has unstable labour market conditions. It will then subject to empirical scrutiny the work of Pongratz and Voß (2003) and evaluate the appropriateness of their typology given the experiences of these developers.

\section{The heroic entrepreneur?}

A traditional mainstream view of enterprise is the self-made heroic entrepreneur, centred around positive images of successful independent businesses. Such rhetoric of an 'enterprising self' (Du Gay, 1996) has led to an ethos of enterprise that has consumed parts of entrepreneurial discourse. The heart of the argument focuses on an individual's capacity to be enterprising whether through risk taking, creativity or self-reliance (Down, 2010: Beck, 1997). 
Developments in the 'new economy' have influenced a movement towards self-employment, and a workforce characterised by entrepreneurial activity. Political encouragement of SME's in combination with structural changes to firms, innovations in technology and lean techniques have resulted in more outsourced and subcontracted work (Grimshaw et al., 2001), encouraging individuals to undertake entrepreneurial activity. Furthermore, attitudes towards self-employment are underpinned by perceptions of increased freedom and personal choice and recognised as an additional motivator (Bogenhold and Stabler, 1991). This characterisation of enterprise is coupled with entrepreneurial career forms, such as the 'boundaryless' or 'portfolio' career, which have emerged in academic discourse and highlight the positive benefits of flexibility and choice (Defillippi and Arthur, 1996) encapsulated by the "free agent" mentality by which individuals utilise their labour power in secure markets to achieve better conditions (Baldry et al, 2007).

In contrast to the predominantly optimistic interpretations of entrepreneurial activity, alternative views highlight the negative implications for individuals, which include anxiety about the short term nature of work (Sennett 1998) and its increasingly fragmented nature (Marchington et al 2005). This alternative perspective suggests changing structural forces have led to some people facing limited options in terms of employment. Limited options may include workers being 'forced' to participate in involuntary self-employment due to the erosion of conventional organisational structures resulting from the use of new technologies, outsourcing and the vertical integration of firms (Kautomen et al 2010). This 'forced' self-employment can occur when an employer redefines a task that has been conventionally performed in a standard employment relationship but is converted into a sub-contracting arrangement.

\section{Creative Industries and Labour Markets}

Employment in creative industries is celebrated as flexible, liberating and 'cool' (Reeves, 2001). However, more detailed analysis of creative work suggests the bohemian, autonomous creative worker enjoying a 'boundaryless career' replete with excitement, flexibility and prestige 
appears less than convincing (Hesmondhalgh and Baker, 2009). In many creative industries differing methods of production have influenced work arrangements resulting in new forms of employment relationships characterised by project based work, temporary contracts, and freelancing (Blair, 2009; Barley and Kunda, 2004). In addition, numerous cultural workers were effectively pushed into self-employment in the 1980's in search of self-exploration and selffulfilment due to the economic recession, industrial downsizing and a lack of government subsidy for the arts and culture (Leadbeater and Oakley 1999). These competitive and regulatory changes have led to unstable labour market conditions that characterise the creative industries (Haunschild and Eikhof, 2009). In the software industry, individuals have found jobs restricted due to sectoral restructuring and downturn (Warhurst et al 2006). Precarity is commonplace for many creative workers, for whom 'star performers' excepted, work is characterised by excessive labour supply and insufficient demand (Smith and McKinlay 2009).

Insecure labour market conditions have led to the growth of short-term contracts, limited job protection and uncertain career prospects (Hesmondhalgh and Baker 2009). Consequently, creative workers are expected to be 'flexible', committing themselves to the commercial imperatives of the firm over non-work commitments (Banks, 2007) and relocating to wherever the job might take them (Haunschild and Eikhof, 2009). Long hours and poor work-life balance portray the industry as having a "ruthless work regiment" suggesting at best that workers feel ambivalent towards these brutal working conditions, which contest the "cool" and "liberating" image of working in the sector (Hesmondhalgh and Baker 2009).

Levels of insecurity, which typify the creative industries generally, are also visible in the digital games sector. Typically, the industry is represented by project-based work where labour is constitutively unstable (Peuter and Dyer-Witheford, 2005, Izushi and Aoyama, 2006). Due to its youth and the constant drive for creativity and innovation, employment follows a flexible employment model characterised by temporary and sub contracts, and free agent self-guided career patterns (Cadin et al 2006). The flexible employment model provides labour market 
conditions which are, at best, unstable for workers due to the casual nature of employment (Peuter and Dyer-Witheford, 2005).

\section{The cultural entrepreneur}

Sectoral and labour market shifts have been reinforced by political discourse and media commentary, which positively encourage enterprise in the digital sector. The political remodelling from the cultural to creative industries, putting enterprise at the heart of the creative sector (Garnham, 2005), along with the drive for creative workers to develop entrepreneurial skills (Hesmondhalgh and Banks,2009), have gone some way to altering expectations and developing a 'creative class' of entrepreneurs (Coulsen,2012). Policy initiatives, such as the Blueprint for Technology (2010), have combined with political rhetoric to illustrate the wealth of opportunity that ostensibly available for workers willing to take up entrepreneurial activity. Media rhetoric highlighting the success of games such as Angry Birds along with success stories of digital entrepreneurs such as Mark Zuckerberg further encourage the celebration of enterprise in the digital sector.

The concept of the cultural entrepreneur broadly follows the new form of labour supply conceptualised by Pongratz and Voß (2003) as the 'entreployee', where an employee redefines their productive capacity within the workplace and the wider labour market. The original conceptualisation is distinct from self-employed workers and refers to the "increased entrepreneurial handling of one own work capacities" within firms. Market conditions and changing structural factors are steering the active promotion of employee responsibility and a more entrepreneurial manner in both the workplace and the wider labour market (Pongratz and Voß,2003:2). In an important extension of this framework, Pongratz (2008) put forward the notion of a 'society of entrepreneurs' as workers increasingly face the need to act as an entrepreneur in its various forms, which include that of the self-employed and the freelancer.

According to Pongratz and Voß (2003:3) the 'entreployee' is characterised by three features: 
Self-control - Intensified independent planning, control and monitoring of work by the person responsible. Self- commercialisation - Intensified active and practical 'production' and commercialisation of one's own capacities and potential on the labour market as well as within companies. Self-rationalisation - Self determined organisation of one daily life and long term plans, and the tendency to accept willingly the importance of the company (employer) as an integral part of life.

The extension of the 'entreployee' framework by Pongratz (2008) to wider entrepreneurial functions means that the conceptualisation is particularly useful for analysing digital gaming given the wider context of changing market structures, the increasingly competitive environment, and the political climate which encourages entrepreneurial activity. Research by Haunschild and Eikhof (2009) and Bergvall-Kåreborn and Howcroft (2013) have used the characterisation of the 'entreployee' to illustrate how workers have taken on entrepreneurial functions in challenging labour market conditions. This article will add to this body of research by examining the relationship between the labour market and entrepreneurialism/enterprise within the digital games sector. Specifically, the study seeks to examine the extent to which the categories outlined by Pongratz and Voß (2003) capture the lived experience of digital games developers.

\section{Methodology}

The fieldwork took place in 2012 in various locations in North West England, which contains a creative cluster for game development that has recently undergone a number of structural changes (Nesta, 2010). In 2009, the North West had a number of large game studios employing over 360 employees and turning over $£ 30$ million (Phillips et al, 2009). Since 2009 the region’s major studios have suffered downsizing or closure, which have had a significant impact on employment, resulting in the emergence of smaller independent firms. As compared with other regional clusters, one distinctive characteristic of the North West of England is that a 
significant number of development studios have been recently acquired by foreign owned publishers, so that the sector has a greater number of independent developers (Phillips et al, 2009, Nesta, 2010).

A qualitative approach combined semi-structured interviews with developers, as well as an ethnography of local networking events. Initial exploratory conversations with senior management and experienced developers concentrated on market trends and the changing dynamics of the sector. This preliminary stage was followed by further research investigating how these issues impacted on individual experiences of developers and covered topics such as motivation for entering into the digital games sector, perceptions of the labour market, working practices, working hours, strategies for entering/movement in the labour market, and the effect of working conditions.

The developers produced a mix of PC and mobile games with around 60 per cent of respondents operating as self-employed 'Indie' or freelance developers. While the study was specifically aimed at self-employed developers, it included developers in full-time employment, graduates looking to enter the labour market, recruitment agents, and game development lecturers, in order to add further context (Appendix 1). The developers interviewed represented a varied grouping as the sample was taken from a mix of ages and roles within the sector in order to capture a wide range of experiences. However, there was a gender imbalance in the research given the under-representation of women, indicative of wider trends within the software sector (Adam, et al 2006). Initially, respondents were contacted by 'cold call' emails and asked to participate in the study. Other respondents were gathered via a mailing list circulated after networking events, following initial face-to-face contact. In total, twenty interviews were carried out and included a mixture of face-to-face discussions or via SKYPE and lasted between 25 minutes and one hour. All interviews were recorded and transcribed.

The digital games sector is heavily reliant for attracting labour on social networks, which are seen to be key to determining the industry's evolution and competitiveness (Izushi and 
Aoyama, 2006). Therefore, in order to capture the wider context, the research involved an 'overt ethnography' at a number of networking events (Appendix 2). At these networking events the purpose and intentions of the research were fully disclosed, allowing the researcher to provide a credible explanation for detailed probing, questioning and participation. Activities at these events included a twitter wall allowing developers to make 'real time' comments during the proceedings, a game development-based 'pub quiz', as well as question and answer sessions with organisers and guest speakers. Usually, the networking events ended with informal drinks or live music, intended to encourage attendees to interact. The events took place in various North West locations, often in the functions rooms of bars and hotels. The number of attendees ranged from 20 to as many as 150 people from the software and game development sectors. Participating in these events enabled the researcher to 'forge relationships, engage in informal conversations, and gather perspectives on the sector. This ethnography allowed the researcher, acting as participant, to go beyond interviews by meeting developers in their own domain, giving additional insights into the culture and behaviours of the group (Creswell, 2013).

Data collection and analysis occurred simultaneously and as an on-going reflective process and coded by the use of a data analysis tool (NVivo). A number of themes, such as challenging labour market conditions, precarity of work and the importance of establishing and managing networks, became apparent. During analysis, the themes identified by Pongratz and Voß (2003) were particularly pertinent and elaborated by respondents. These questions were then probed by the researcher to provide additional detail. Furthermore, as developers described their movements between full-time employment, working on projects, freelancing, and 'indie' development, their reflections mirrored the 'society of entrepreneurs' identified by Pongratz (2008), and so particular emphasis is paid to the self-employed developers in this study.

\section{The dark side to enterprise}


The analysis will begin with a section that focuses on market conditions in the region. This will highlight a number of key factors that have influenced developers towards self- employment. The intention is not to suggest the conditions of digital game developers are unique, but illustrate how these conditions provide a useful locus for examining entrepreneurial activity in the context of the Pongratz and Voß (2003) framework.

\section{Encouraging self-employment}

The lack of market and, in consequence labour market, predictability entailed that employees were commonly employed on a freelance or contract basis in order to reduce risk amid volatile conditions. Firms were acutely aware that permanent employees were a potential drain on resources given the changing macro conditions. The reaction was to use freelancers and contractors on a project by project basis, giving firms greater flexibility.

We're very lean.... we tend to operate more on a outsourced model, so wherever possible we try not to take on resourced on a permanent basis because it's too volatile......so we put people on fixed term contracts for specific items of work (Chief Operating Officer, male, early forties, 1).

The workforce planning strategy replicated in some respects the flexible firm model (Atkinson, 1985), in which peripheral employment contracts and conditions were created by employers in response to erratic market conditions. For developers such strategy exacerbated unstable work. The use of freelancers and contractors was generally accepted by developers and seen as representative of the working culture in the sector. Developers expressed how they needed to adapt to these changing conditions in order to gain employment, thus encouraging higher levels of self-employment. 
The change in constitution of the 'creative cluster' in the mid- to late-2000's was attributed to various factors. Senior management cited that the withdrawal of tax breaks, combined with low costs locations offering cheaper production, gave firms sound economic reasons for moving production to different geographical locations. Locations such as Canada and Ireland that offered tax advantages or India and Russia that were described as low cost areas of production, enticed digital games firms to move production, thereby encouraging the closure of studios in the region. By 2012 several large studios had either shut or slimmed down leaving one large studio in the region. Examples of this included Sony Computer Entertainment (SCE) and Bizarre Creations. Some developers reflected on the impact on their prospects of employment within the sector. 'I think there's a lot of people finding themselves between work. Especially around here there's a lot fewer big companies' (Flash developer, male, late twenties, 15).

One response to this trend was that developers set up as an independent company or as a freelancer in order to find work. One particular developer (also the organiser of a local networking group) noted that the number of independent companies had grown as a response to companies shutting down.

A lot of people set up their own independents especially from Bizarre Creations such as Cowrocket and M2 games, it turns out quite a lot have built up around these companies falling apart (Freelancer, male, early twenties,9).

This finding was supported by observers of the sector who explained that, as jobs become increasingly scarce, individuals were forced to look for alternative ways to make a living as selfemployment was viewed as viable.

There are only a finite number of jobs within the industry, and if one or two big developers have suddenly gone pop where do all those people go? Where are they absorbed? So it makes sense that they start their own (Lecturer, male, early forties, 17). 
In addition to structural changes, developers highlighted how new platforms for development had lowered barriers to entry, making self-employment more feasible. A payment fee to Apple was noted as a small price to pay to start distributing games on the iOS platform. Google and Microsoft platforms were seen as similarly less restrictive, giving independent firms the opportunity to publish games outside of the traditional value chain. Independent developers discussed how this gave them the ability to make a living producing games independently.

I believe it's a very good time to start your own business with platforms like Steam and IOS. It's so easy to make a game, post it on there and start making money. There's no need for publishers (Co-owner, male, early twenties, 13).

Changing market conditions have influenced entrepreneurial and enterprising activity in the sector as organisational strategies for managing instability have led to an increase in the use of outsourced labour. Changes to the constitution of firms have led many developers to look for alternative types of work, with many opting for self-employment. This emerging trend has coincided with increased accessibility to development platforms, which has lowered barriers to entry and made independent development more viable.

\section{Self-Control}

Pongratz and Voß (2003) suggest that individuals have to plan, control and monitor their own work activities. Most developers described their working hours as 9-5 but highlighted that the flexibility of self-employment gave them the option of working when they chose.

We do work kind of 9 to 5 broadly. It's easier for me because I tend to do more of the graphics side of it and data and websites. It's a little bit more just regular working hours. Jim works in bursts. So it's something he struggles with because he'll often have 
two or three days of doing nothing but follows up by a mad burst to get loads of work done (Co-owner, male, late forties,5).

As the nature of the work is highly dependent on creativity, such as idea creation and problem solving during game play, some developers found that this process of development did not conform to standard working hours. The flexibility provided by self-employment gave developers the ability to organise their work around the creative process. However, flexibility is not without problems:

My partner forces himself to start coding...he struggles with it because he feels guilty if he's not working and feels like he should be sat there 9 to 5 doing eight hours of coding a day but he knows his brain doesn't work that way. So he works on an on/off kind of way but we try to work as much as possible to stick to office hours (Co-owner, male, late forties, 5).

When setting one's own hours some developers tried to replicate traditional 9-5 working patterns wherever possible as this complemented their non-work commitments. However, other developers highlighted that working as an independent developer meant that there was no one regular 'working shift', which allowed them to plan their time in a way they would not be able to in a normal studio environment.

While recognising that unstable labour market conditions influenced self-employment, this was not cited as their primary reason for becoming self-employed. Creative control was a major reason why some developers opted for self-employment. Developers talked about making games without being constrained by commercial imperatives likening themselves to other areas of the creative industries, which were believed to enjoy more creative freedom.

We're like songwriters we've got ideas rattling around in our heads that we want to get out. It's not really making games because of a career choice or the best way to make 
money, we feel compelled to do it because we've got ideas in there that we want to do, we weren't allowed to get any of it out in console development (Co-owner, male, late forties, 5).

During networking events, self-employed developers regularly discussed the attraction of being part of a small development team. In interviews developers discussed the importance of making a variety of smaller games rather than making one large title and suggested that this provided more control over what they do.

Being masters of our own destiny is definitely one of the reasons why many of us moved to mobile ....... I remember my mate, he had just worked on Night-racer, I said 'what did you do on it'. He continues 'you know the bit at the start where it goes 3, 2, 1, yeah I wrote that'. So on this huge game he polished one nut whereas that year our team had written three games (Co-owner, male, early forties, 4).

However, the creative control independent developers sought when going 'indie' was contrasted with making games that would appeal to the market. While some developers articulated that they were making games that were creatively appealing to them, these were often on platforms and in genres that reflected market norms, suggesting that the freedom and creativity they pursued was to be reconciled with market demands.

When planning and monitoring their work activities, one of the major challenges was earning sufficient income. The time delay between releasing the game and revenue generation meant that developers had to carefully plan the work while considering future rewards.

At the moment we've got money coming in from Adventure Pool, which was originally released last year, but we're working on two different games. So the money's coming in based on last year's work and the work we're doing now probably won't bring any 
money until the end of this year. So it's that sort of disconnect that you have to tell yourself, there isn't a direct feedback, if I work double hard this week I'm not going to make double money this week (Co-owner, male, late forties, 5).

Many developers would counter the insecurity of not knowing whether their own games would be successful by undertaking additional work to ensure a regular income. Job roles consisted of freelance software work, teaching games students and part-time work outside of the sector. At the same time, respondents understood the need to balance any additional work with working on their own games. Developers discussed their desire to gain extra funding, as this offered a means for securing future income and would enable them to take on less additional work, concentrating on their own games.

I'm applying to the Prototype Fund, there's a lot of help for start-up companies. We just sent our application format video to the University prototype fund. I think its $£ 25,000$ so if we get that, hopefully we'll be able to work on it as much as we can (Owner, male, early forties, 2).

At networking events self-employed developers actively spend time seeking out developers who had achieved funding. They were keen to know about the types of funding available, the process of application, and how much time this may entail. Developers with funding were generally prepared to share their experiences. Successful developers were held in high esteem by their peers, as securing funding for their own projects resulted in increased autonomy over their working conditions.

Developers spent a significant amount of time planning and managing their own work to try to ensure a reliable cash flow. The autonomous and free notion of the creative industries seems far from the everyday working experiences of these developers. While they cited creative freedom and self-control as reasons for being self-employed, many by contrast acknowledged and responded to market demands when developing a product, taking on additional work, or 
spending time chasing funding in order to wrest more control, freedom and independence in their work.

\section{Self-Commercialisation}

Pongratz and Voß (2003) highlight self-commercialisation as a key function of the 'entreployee', stating that active production and commercialisation of one's own capacities is vital within the firm and the labour market. Respondents noted that gaining work or future employment opportunities was heavily dependent social networks. Developers actively developed their personal network and showcased their skills at networking events in order to generate work. Developers and sector observers commented on the close knit nature of regional sector and the influence of connections in finding work.

The industry is so small anyway, the way to get the jobs and the contracts is to know people. I go to a lot of events and conferences and I know a lot of people, so when I'm looking for something I'll email them or when I'm at a conference someone might say I'm working on a project and I don't have this yet and I'Il say hey, that's what I do (Freelancer, male, early twenties, 9).

Self-employed developers find networking to be a key part in developing a firm's reputation for finding collaborators:

Networking is the easiest way into a job or the easiest way into collaborations between studios. I think it's really important to network, get yourself out there for people to know who you are as a studio and who belongs to that studio. So yes, getting yourself out there as much as you can, getting feedback for your game can only be beneficial (Co-owner and environmental artist, male, early twenties, 14). 
Observations at networking events revealed the strong sense of occupational community within the sector. Developers would socialise together, forge friendships and actively support each other in finding work. Developers directed work towards their peers if its content lay beyond their skill set or they were busy working on other projects. They would actively network in order to seek out possible collaborations with more established 'Indie' developers. Aside from circulating business cards, developers would use more creative means to illustrate their skills and experiences, such as using mobiles phones and tablet computers to show potential collaborators their portfolio of work. Developers would also self-commercialise through the use of the twitter wall to promote their skills and indicate their availability to help out on projects. This initiative was encouraged by event organisers as 'tweets' posted to the wall would be read out intermittently to encourage further tweets and to support the developers' collaborative activity.

Online networking was used by developers to scan the market for jobs and make use of discussion boards, forums and newsfeeds.

I'm on LinkedIn and obviously on twitter as well which is a good tool that a lot of people are using now, you can always see lots of jobs and things advertised on twitter and get passed around so yeah, I have been trying to make use of those (Graduate looking to enter the industry, male, early twenties, 12).

Other developers talked about online networking as a work task given the reputation benefits. For example, a co-owner of an independent firm stated,

It is work, it brings us in money and by people knowing about us a couple of clients have contacted us and said, 'We've heard about you through Twitter.' So, yes, you need to treat it like work (Co-owner, male, early twenties, 11). 
Another tactic used by developers to gain work or position themselves in the industry was to work for free or for a share of future profits. This appeared to be accepted as a legitimate way to enter the industry or to gain experience or exposure, particularly among less established developers, as the two following quotes illustrate.

Even before I got my degree I found out that LW Games was an employment freeze. So I offered just to get my foot in the door saying I'll work for free for $\mathrm{X}$ amount of months until there's a place open. And they went, 'oh yeah, great, jump aboard,'. So I worked for free for three months.........it was very risky. I was penniless for a while. But it was worth it in the end, now I've moved out, got a great job. It's paid off really well (Full time flash developer, male, late twenties, 15).

This is my Master's degree as well, so I'd be doing work regardless, I'm doing work for an actual game that's going to be published. So I've got to really count my chickens and not think I'm not getting paid (Co-owner and environmental artist, male, early twenties, 14).

Working for free in return for a share of future profits was explained by some developers as a more collaborative way of making games and was regarded as an acceptable arrangement, given the experience they were gaining and the hope that the product they were working on would be a commercial success. Nevertheless, profitability cannot be guaranteed given the market's unpredictability. One independent developer highlighted the common arrangement,

No one earns anything until something is shipped and incentive there is for people to finish a project so if you don't finish it you don't get paid and then base the profit share on the content and the effort you have put in. (Owner, male, early forties, 2)

Discussions at networking groups and the testimony of a majority of respondents suggested that working for a potential share of the profits, rather than a salary, was common practice. 
Such a finding is consistent with evidence from elsewhere in the creative industries where unpaid work is prevalent (Ross, 2003).

\section{Self-rationalisation}

The final characteristic of the 'entreployee' conceptualisation relates to the self-determined organisation of daily life and long term plans, including the willingness to accept the centrality of work in one's life (Pongratz and Voß ,2003). Respondents discussed the intensive nature of project work and highlighted that 'crunch' (a practice widely used in the sector where employees work long hours in order to finish a project, Peuter and Dyer-Witheford,2005 ) was relatively normal. Respondents noted the brutal nature of the sector.

Space Wings, I mean did you read in the news the other day that they got number one.... It's amazing what you can do with slavery, isn't it?...My mate, used to work for Space Wings and you're expected to crunch. It's not in the contract, but it might as well be. You're just expected to work and it's bleak. If you don't do the crunch then you're frowned upon, then if you get frowned upon you get fired (Full time flash developer, male, late twenties, 15).

Self-employed developers accepted the reality of long hours, describing the condition as 'just the way it is' and as representing passion for your work.

You wake up at 9 am, start working and go to sleep at 2 in the morning you have to be passionate about what you're doing (Co-owner, male, early twenties, 13).

For self-employed developers taking additional jobs could mean working more than 50 hours in a week. Taking on additional work was widespread amongst the developers interviewed and 
reflected nine respondent's experiences. One particular case concerns that of a developer who was employed full-time by a zoo:

Working day jobs is not ideal, it's not something we mention often........ usually spend about 40 hours a week on zoo related things, I work until about 8-5 or 6 in zoo time then about 7 till 10 is my project game time and with any days off I get (Co-owner, male, early twenties, 11).

The working of long hours was rationalised by developers as necessary to the achievement of success as a developer.

I'm currently a part time Manager at Tesco, I do about 40 hours a week. So add another 20. It does get difficult, but at the end of the day the company's profit and success is basically measured on how much we want it. It depends on how much we want to do, we're not just fooling around, we are $100 \%$ in tune with each other, me and Will. So we will just work through the night and stay awake basically (Co-owner, male, early twenties, 10).

Developers also indicated that they were willing to accept the centrality of work in their everyday lives by illustrating their flexibility, working even when they were 'off work' either in personal time or on holiday. An ability to commit to these demands was facilitated by their use of ICT's which kept them constantly connected to work.

I can go out and if there is anything particularly urgent they can give me a bell. With mobile phones you can answer emails and tweet from anywhere...so far I haven't had a holiday [but] I would imagine if I was going to I would say if there was anything you needed me to do I would sort it out (Freelancer, male, early twenties, 9). 
This evidence suggests that 'crunch' is present not just in large studios, but exists also in small independent development teams. There is some ambivalence towards long hours and demanding working conditions. Being 'on call' was seen as expected by employers and refusal to respond to requests to work could potentially impact on developers' opportunities for future employment.

\section{Discussion and Conclusion}

This article has explored how changing market structures and unstable labour market conditions have contributed to growing entrepreneurialism in the digital games sector. Additionally, it has considered the effects on the working lives of developers. Wider media and political celebrations of enterprise are perhaps best understood in the context of austerity. This study has demonstrated that in the context of the digital games sector such rhetoric appears divorced from the work lives of developers. Increased outsourcing, growing casual employment and technological changes appear to have encouraged self-employment, but developers are often left with little alternative other than 'involuntary entrepreneurship' (Kautomen et al, 2010). Despite challenging work conditions, many developers remain confident and optimistic about their working lives, choosing not to cite difficult labour market conditions as the primary reason for becoming self-employed. Instead, developers construct narratives of success and satisfaction, citing positively how self-employment offers freedom to manage one's own destiny, creativity, and engage in work that is self-actualising.

Using Pongratz and Voß's (2003) conceptualisation of the 'entreployee', this exploratory study has revealed the reactions of developers to difficult business and labour market conditions as they try to ensure their economic survival and secure remunerative employment. Developers cited control, freedom and autonomy as major reasons for pursuing self-employment, notwithstanding the context of widespread structural changes in the sector that might narrow the possibilities for such self-employment. Self-employed developers still have to work to deadlines, but how they achieve these targets was self-determined and subject to how they 
manage their own working hours and activities, albeit not in circumstances of their own choosing. Their exercise of autonomy occurs within the boundaries of market demands, which contrasts with the flexible, liberating and cool (Reeves, 2001) notion of employment in the creative industries, suggesting that freedom and choice are unattainable (Hesmondhalgh and Baker 2009).

Self-control appeared to be eroded as market conditions dictated developers take on additional work to fund their own projects. The study found that self-commercialisation is as important in the digital games sector as in others areas of the creative industries (Hesmondhalgh and Baker, 2010), with developers working for free as a legitimate way to establish themselves and develop their reputation in the sector.

Literature from the creative industries reveals the importance of networking as a means of gaining future employment or securing collaboration (Hesmondhalgh and Baker 2010, Barley and Kunda, 2004), to the extent that Blair et al (2003) render skills ineffective without the social contacts to leverage. Hence, networking is viewed instrumentally rather than simply 'catching up' (Wittel, 2003) as developers found this to be crucial to self-commercialising. If developers were unable or unwilling to take part in such activities their chances of obtaining work would be weakened, thus limiting opportunities in the sector. Various strategies to self-commercialise extend the working week, intensify work, and blur the boundaries between work and private life. The extension of working hours and willingness to accept the centrality of work as part of developers' lives was rationalised by the belief that this illustrated their passion for the work and was an accepted norm in the sector.

The findings from this research point to the emergence of a new characteristic of Pongratz and Voß's (2003) conceptualisation of the 'entreployee'. While the authors discuss selfrationalisation as one of the key features of the 'entreployee', evidence from this study suggests that developers have to go beyond this feature and further redefine their capacity in the workplace. Therefore an additional feature of the 'entreployee' is 'an acceptance or 
willingness to self-exploit or be exploited'. This study has revealed how developers have shown willingness to self-exploit or be exploited in two ways. Firstly, self-exploitation involves working for 'free' and exploiting their time, ideas and intellectual property in order to get 'experience' or gain exposure in the sector. The second aspect concerns working well beyond the realms of a 'working week', effectively being 'on call' to the demands of employers or in order explore opportunities that may increase their potential success in the sector.

The practice of working for free was seen as commonplace and was positively reinforced by the occupational community who viewed it as ways of enhancing developers' employability and of making money. Despite the fact that performing unpaid labour was viewed as contributing collaboratively to making games, it was also undertaken in the belief that a game would become commercially successful. However, the unpredictability of the games market suggests that there is no guarantee that developers will receive financial payment for this work. Working beyond the 'working week' included developers engaging in diverse activities, including networking on and off line and outside of normal working hours in order to establish themselves in the sector due to competitive labour market conditions. Furthermore, it was necessary for some developers to work long hours at additional 'day jobs' in order to assist in the financing of their independent businesses and wrest more control and independence over their work in the future.

According to the evidence from this limited number of interviews, developers appear satisfied with their working conditions. However, digital gaming is not dissimilar to other areas of creative work which display an exploitative element (Arvidsson, 2010; Hesmondhalgh and Baker, 2009). Rather than expressing unease about their working conditions, the developers in this study seem to accept their exploitation. This corresponds with work in other areas of the creative industries where temporary workers fail are unable to resist exploitative practices given the pleasure of the job, the sense that self-actualising work reinforces their identity and their consent to exploitation will lead to developers receiving financial and psychological benefits in the future (Ursell 2000; Ross, 2003). 
This article then contributes towards the literature on the digital gaming sector and to the specific focus on entrepreneurialism, which is largely absent. It provides a critical assessment of the impact of entrepreneurialism and enterprise on individuals' working lives, building on research from Pongratz and Voß (2003) Haunschild and Eikhof, (2009) and Bergvall-Kåreborn and Howcroft (2013). However, the data in this study derives from a numerically small sample of respondents from a relatively narrow geographical context. Consequently, the therefore this study is best seen as exploratory and does not make grand claims of generalizability. Nevertheless, it provides compelling insights into the working experiences of a cohort of developers in the digital games sector and further research in the area would help to establish whether these tentative findings are indicative of definite trends.

\section{References}

Adam, A., Griffiths, M., Keogh, C., Moore, K., Richardson, H. and Tattersall, A. (2006), "Being an 'it' in IT: Gendered Identities in the IT Workplace." European Journal of Information Systems, 15(4), pp. 368-378.

Atkinson, J. (1985)" Flexibility: planning for an uncertain future". Manpower Policy and Practice, Vol 1,pp. 26-29.

Arvidsson, A. E., Malossi, G., Naro, S. (2010). “Passionate work? Labour conditions in the Milan fashion industry." Journal for Cultural Research, 14 (3). pp.295-309.

Banks, M.(2007). The Politics of Cultural Work. Basingstoke, UK: Palgrave.

Baines, S. (1999) "Servicing the Media: Freelancing, Teleworking and 'Enterprising Careers". New Technology, Work and Employment. 14. (1)pp.18-31 
Baldry C, Bain P, Taylor P, Hyman J, Scholarios D, Marks A, et al. (2007) The Meaning of Work in the New Economy. Basingstoke: Palgrave Macmillan.

Barley, S. R., and Kunda, G. (2004) Gurus, Hired Guns, and Warm Bodies: Itinerant Experts in a Knowledge Economy. Princeton, NJ: Princeton University Press.

Beck, U.(1992) Risk society: towards a new modernity, London, Sage.

Bergvall-Kåreborn, B. and Howcroft.D. (2013) "'The Future's Bright, the Future's Mobile': A Study of Apple and Google Mobile Application Developers." Work, Employment and Society. 27 (6). pp.964-981

Blair, H. (2009). "Active Networking: Action, Social Structure and the Process of Networking". In: Smith, Chr./McKinlay, A. (eds.): Creative Labour. Working in the Creative Industries. Basingstoke: Palgrave, pp.116-135.

Bogenhold, D , and Stabler.,(1991). "The decline and rise of self-employment". Work, employment and Society, Vol 5(2).pp 223-239

Department for Business, Innovation and Skills. (2010). Blueprint for Technology.

Cadin, L. and Guerin, F. (2006). "What Can We Learn from the Video Games Industry?" European Management Journal. 24(4), pp.248-255.

Cohendet, P. and Simon, L. (2007) “Playing across the playground: paradoxes of knowledge creation in the videogame firm." Journal of Organizational Behaviour, 28 (5): pp.587-605.

Coulsen, S. (2012) “Collaborating in a Competative world: musicians' Working lives and Understanding of Entrepreneurship." Work Employment and Society. 26 (2) pp.246-261. 
Crang, M. \& Cook, I. (2007). Doing Ethnographies. London: Sage

DeFillippi, R. J., and M. B. Arthur.( 1996). Boundaryless contexts and careers: A competencybased perspective. Oxford: Oxford University Press

Down, S. (2010). Enterprise, Entrepreneurship and Small Business. London: Sage.

Eikhof, D. and Haunschild, A. (2009) "Bringing Creativity to Market. Theatre Actors as Self-employed Employees." In: Smith, Chr./McKinlay, A. (eds.): Creative Labour. Working in the Creative Industries. Basingstoke: Palgrave, pp.156-173.

Garnham, N. (2005) "From Cultural to Creative Industries." International Journal of Cultural Policy. 11(1): pp.15-29.

Grimshaw, D., Beynon, H., Rubery, J. and Ward,K. (2002) "The restructuring of career paths in large service sector organisations: "delayering", upskilling and polarisation", Sociological Review, Vol 3. pp 89-115.

Hesmondhalgh D. Baker S. (2010) “'A very complicated version of freedom': Conditions and experiences of creative labour in three cultural industries", Poetics.38(1): pp.4-20.

Hesmondhalgh D. and Banks M. (2009) "Looking for work in creative industries policy." International Journal of Cultural Policy.15.4: pp.415-430.

Izushi, H and Aoyama, Y.(2006). "Industry evolution and cross-sectoral skill transfers: a comparative analysis of the video game industry in Japan, the United States, and the United Kingdom". Environment and Planning. Vol 38:pp. 1843-1861. 
Kautonen, T., Down, S., Welter, F., Vainio, P., Althoff, K., Kantola, J. and Kolb, S. (2010)

"Involuntary Self-employment' as a public policy issue: A cross-country EU comparison."

International Journal of Entrepreneurial Behaviour and Research 16(2): pp.112-129.

Keynote, (2014). Market Report: Video Gaming. Keynote

Keynote, (2013). Market Report: Home Entertainment. Keynote

Leadbeater, C. and Oakley, K. (1999). The independents: Britain's New Cultural Entrepreneurs. Demos. London.

Lampel, J., Lant, T. and Shamsie, J. (2000). "Balancing Act: Learning from organizing practices in cultural industries." Organization Science 11(3): pp.263:269.

Marchington, M P., Grimshaw, D., Rubery, J., Willmott, H. (2005) Fragmenting Work:Blurring Organisational Boundaries and Disordering Hierarchies. Oxford. Oxford University Press

Nesta, (2010). Creative Clusters and Innovation. London. Nesta

Parker, R., Cox, S,. and Thompson,. P. (2014). How Technological change affects power relations in global markets:remote developers in the console and mobile games industry. Environment and Planning A.46.pp 168-185.

Peuter, G. and Dyer-Witheford, N. (2005) “A Playful Multitude? Mobilising and Counter Mobilising Immaterial Game Labour." Fibreculture, 5.

Perlow, L. (1997) Finding Time: How Corporations, Individuals and Families Can Benefit from New Work Practices. Ithaca, NY: Cornell University Press. 
Phillips, R., Latham, W., Hodgson, D., Corden, J., Jordan, J. Minshall, T. and Wharton, L. (2009). In Search for Excellence: A Comparative Business Model Assessment Of Value Creation Capabilities In The Computer Games Sector. North West Development Agency.

Pongratz, H.J. and Voß. G.G. (2003) Arbeitskraftunternehmer. Erwerbsorientierungen inentgrenzten Arbeitsformen. Berlin: edition sigma.

Pongratz, H., (2008): Gesellschaft von Unternehmern, E.: Expansion und Profanierung "schöpferischer Zerstörung" in kapitalistischen Ökonomien. In: Berliner Journal für Soziologie 18, pp.457-475.

Ross, A. (2003) No-collar: The Humane Workplace and Its Hidden Costs. New York: Basic Books.

Smith, C. and McKinlay, A. (2009). Creative Labour: Working in the Creative Industries. Basingstoke: Palgrave.

Skilton, P. F. (2009). “Knowledge Based Resources, Property Based Resources And Supplier Bargaining Power In Hollywood Motion Picture Projects." Journal of Business Research, 62(8),pp 834-840

Skillset (2011) Computer Games Sector: Labour Market Intelligence Digest. In Skillset (Ed.). London, Skillset.

Stewart, J,.Misuraca, G (2013). The Industry and Policy Context for Digital Games for Empowerment and Inclusion. European Commission

Tschang, F. T. (2007). "Balancing the Tensions between Rationalization and Creativity in the Video Games Industry." Organization Science 18(6): pp.989-1005. 
Reeves, R. (2001) Happy Mondays: Putting the Pleasure Back into Work. London: Momentum.

Robinson, E. (2005). Why Crunch Mode Doesn't Work: 6 Lessons, IGDA.

Ursell, G. (2000) 'Television Production: Issues of Exploitation, Commodification and

Subjectivity in UK Television Markets', Media, Culture \& Society 22(6):

805-25.

Warhurst, C., Lockyer, C. and Dutton, E. (2006) “IT Jobs: Opportunities for All?” New

Technology, Work and Employment. 21 (1). Pp.75-88

Wittel, A., 2001. "Toward a Network Sociality." Theory, Culture and Society 18 (6), pp.51-76.

Zackariasson, P., Styhre, A. and Wilson, T. (2006), "Phronesis and Creativity: Knowledge Work in Video Game Development." Creativity And Innovation Management,15,(4). pp. 419-429

\section{Appendix 1}

\section{Respondents}

\begin{tabular}{|l|l|l|l|l|l|}
\hline Number & Age & Gender & Occupation & Location & Interview \\
\hline $\mathbf{1}$ & $\begin{array}{l}\text { Early } \\
\text { Forties }\end{array}$ & Male & Chief Operating Officer & Manchester & Face to Face \\
\hline $\mathbf{2}$ & $\begin{array}{l}\text { Early } \\
\text { Forties }\end{array}$ & Male & Owner & Lymm & Face to Face \\
\hline $\mathbf{3}$ & Late Forties & Male & $\begin{array}{l}\text { Head of Business } \\
\text { Development and co- } \\
\text { owner }\end{array}$ & Macclesfield & Face to Face \\
\hline
\end{tabular}




\begin{tabular}{|c|c|c|c|c|c|}
\hline 4 & $\begin{array}{l}\text { Early } \\
\text { Forties }\end{array}$ & Male & Co-Owner & Manchester & Face to Face \\
\hline 5 & Late Forties & Male & Co-Owner & Manchester & Skype \\
\hline 6 & $\begin{array}{l}\text { Early } \\
\text { Twenties }\end{array}$ & Male & Co-Owner & Manchester & Skype \\
\hline 7 & $\begin{array}{l}\text { Early } \\
\text { Twenties }\end{array}$ & Male & Co-Owner & Manchester & Face to Face \\
\hline 8 & $\begin{array}{l}\text { Early } \\
\text { Twenties }\end{array}$ & Female & $\begin{array}{l}\text { Recruitment } \\
\text { Consultant }\end{array}$ & Wilmslow & Face to Face \\
\hline 9 & \begin{tabular}{|l} 
Early \\
Twenties
\end{tabular} & Male & Freelancer & Chester & Skype \\
\hline 10 & \begin{tabular}{|l} 
Early \\
Twenties
\end{tabular} & Male & Co-Owner & Chester & Skype \\
\hline 11 & \begin{tabular}{|l} 
Early \\
Twenties
\end{tabular} & Male & Co-Owner & Chester & Skype \\
\hline 12 & \begin{tabular}{|l} 
Early \\
Twenties
\end{tabular} & Male & $\begin{array}{l}\text { Graduate looking to } \\
\text { enter the industry }\end{array}$ & Chester & Skype \\
\hline 13 & \begin{tabular}{|l} 
Early \\
Twenties
\end{tabular} & Male & Co-owner & Manchester & Skype \\
\hline 14 & \begin{tabular}{|l} 
Early \\
Twenties
\end{tabular} & Male & $\begin{array}{l}\text { Co-owner and } \\
\text { Environmental Artist }\end{array}$ & Manchester & Skype \\
\hline 15 & \begin{tabular}{|l} 
Late \\
Twenties
\end{tabular} & Male & Flash developer & Wilmslow & Face to Face \\
\hline 16 & $\begin{array}{l}\text { Mid- } \\
\text { Twenties }\end{array}$ & Male & Artist & Wilmslow & Skype \\
\hline 17 & $\begin{array}{l}\text { Early } \\
\text { Forties }\end{array}$ & Male & $\begin{array}{l}\text { Lecturer, Head of } \\
\text { Games }\end{array}$ & Manchester & Face to Face \\
\hline 18 & Early & Male & Artist & Wilmslow & Skype \\
\hline
\end{tabular}




\begin{tabular}{|l|l|l|l|l|l|}
\hline & Twenties & & & & \\
\hline $\mathbf{1 9}$ & $\begin{array}{l}\text { Early } \\
\text { Twenties }\end{array}$ & Female & Artist & Wilmslow & Skype \\
\hline $\mathbf{2 0}$ & $\begin{array}{l}\text { Late } \\
\text { Twenties }\end{array}$ & Female & Owner & Manchester & Skype \\
\hline
\end{tabular}

\section{Appendix 2}

\section{Events}

\begin{tabular}{|l|l|l|}
\hline Name of event & Date & Location \\
\hline Mobile Network & $12 / 03 / 2012$ & Manchester \\
\hline Technology Edge & $21 / 03 / 2012$ & Macclesfield \\
\hline Mobile Network & $10 / 04 / 2012$ & Manchester \\
\hline GDev Meet & $30 / 06 / 2012$ & Chester \\
\hline GDev Meet & & \\
\hline GDev Meet & $11 / 08 / 2012$ & Liverpool \\
\hline
\end{tabular}

